\title{
Characteristics of Runoff Nutrient Loss and Particle Size Distribution of Eroded Sediment under Varied Rainfall Intensities
}

\author{
Guanhua Zhang \\ Soil and Water Conservation Department, Changjiang River Scientific Research Institute, Wuhan \\ 430010, China.
}

Corresponding author: zgh83113@126.com

Keywords: Nutrients loss, runoff and sediment, particle size distribution, simulated rainfall

\begin{abstract}
Soil erosion is a serious problem of worldwide concern. Rainfall intensity is an important factor affecting soil erosion and the resulting nutrients loss. Field experiments were conducted to investigate the effect of rainfall intensity $(60,100$ and $140 \mathrm{~mm} / \mathrm{h})$ on runoff nutrients loss and sediment particles size distribution under simulated rainfall conditions. The results showed that rainfall intensity had a significant effect on runoff, sediment and the associated nutrients loss. In general, higher rainfall intensity led to higher runoff nutrients loss. Furthermore, the nutrients mostly lost through sediment instead of runoff water. Inorganic nitrogen loss was mainly due to runoff, primarily in the form of $\mathrm{NO}_{3}-\mathrm{N}$. Positive linear relationships existed between soil loss and nutrients loss. Rainfall intensity had more significant effects on enrichment ratio of nitrogen $\left(\mathrm{ER}_{\mathrm{N}}\right)$ than that of organic matter (ER $\left.\mathrm{OM}_{\mathrm{OM}}\right)$ and phosphorus $\left(\mathrm{ER}_{\mathrm{P}}\right)$. Compared with the original surface soil, the sediment contained more fine particles $(<20 \mu \mathrm{m})$. The clay content significantly decreased with increasing rainfall intensity $(p<0.05)$. ER of sediment-bound nutrients was positively correlated with ER of particles smaller than $2 \mu \mathrm{m}$. This suggested that the clay fraction $(<2 \mu \mathrm{m})$ was preferentially eroded and soil nutrients were mainly adsorbed on or contained within this part of particles.
\end{abstract}

\section{Introduction}

Soil erosion is a serious eco-environmental problem of worldwide concern. It not only causes on-site loss of topsoil and reduces the land productivity, but also brings about major off-site environmental effects such as water body pollution and eutrophication [1, 2, 3]. This is especially true on the Loess Plateau of China.

Rainfall is the dynamic factor for soil erosion and is mainly shown in several aspects: precipitation, rainfall intensity, rainfall spatial and temporal distribution, rainfall energy, etc. Among which, rainfall intensity is the most important one [4, 5]. Kang [6] and Zhang [7] reported that rainfall intensity, especially short duration rainstorms with higher intensity, was the key factor causing soil erosion and the related nutrients loss on the Chinese Loess Plateau.

Soil fine particles were easily transported by runoff [8]. Soil erosion led to the enrichment of fine particles and chemical elements in sediments [9], which in turn caused the changes in particle size distribution (PSD) of the eroded sediments. Furthermore, Water erosion may cause a redistribution of the soil particles in the surface soil layer and, by modifying the soil texture, can significantly contribute to a deterioration of soil properties [10]. It is important to study the particle size composition of eroded sediment because the properties of sediment eroded from interrill area provides basic information on erosion process and may suggest measures for controlling the off-site effects of sediment in surface waters [11]. In addition, information on eroded sediments is needed for calibrating and verifying erosion models to predict soil losses and sediment quality and therefore implement practices to reduce erosion $[12,13,14]$.

The objective of the present study was to explore the effect of rainfall intensity on runoff, sediment, nutrients loss, and sediment PSD, as well as their relationships. The findings can offer useful insights into the characteristics of runoff, sediment and the associated nutrients loss, and provide scientific guidance for construction of soil and water conservation measures. 


\section{Materials and Methods}

Study area. The study was conducted on field plots at the Ansai Research Station of Soil and Water Conservation from June to September 2008. The experimental station, which belongs to the Chinese Academy of Science, is located 35 km north of Yan'an City in northern Shaanxi Province, China $\left(108^{\circ} 51^{\prime}-109^{\circ} 26^{\prime} \mathrm{E}, 36^{\circ} 30^{\prime}-37^{\circ} 39^{\prime} \mathrm{N}\right.$; average elevation: $1060 \mathrm{~m}$ a.s.l.). With a typical temperate continental semiarid monsoon climate, this area has a mean annual precipitation of 530 $\mathrm{mm}$ that occurs mostly between July and September during summer wet season. Summer rains are characterized by high intensity and short duration; these storms produce significant volumes of surface runoff. Mean annual temperature is $8.8^{\circ} \mathrm{C}$. The soil is classified as a typical loessial soil, representing the most common soil type in the hilly-gully region of the Loess Plateau. Soil in this region is susceptible to erosion and the erosion modulus is more than $10000 \mathrm{t} \mathrm{km}^{-2} \cdot \mathrm{yr}^{-1}$. A variety of soil properties were measured for the experimental plot and the average values are listed in Table 1.

Table 1 Physical-chemical properties of Surface soil $(0-5 \mathrm{~cm})$ in the experiment site (Mean \pm Std)

\begin{tabular}{cccccccc}
\hline \multicolumn{2}{c}{ Nutrients content $(\mathrm{g} / \mathrm{kg})$} & \multirow{2}{*}{$\begin{array}{c}\text { Organic } \\
\text { matter }\end{array}$} & $\mathrm{TN}$ & $\mathrm{TP}$ & $\begin{array}{c}\text { Bulk density } \\
\mathrm{g} / \mathrm{cm}^{3}\end{array}$ & $\begin{array}{c}\text { Porosity } \\
\%\end{array}$ & \multicolumn{3}{c}{ Soil particle composition (\%) } \\
\cline { 7 - 9 } & & & & & $\begin{array}{c}<0.002 \\
\mathrm{~mm}\end{array}$ & $\begin{array}{c}0.002-0.02 \\
\mathrm{~mm}\end{array}$ & $\begin{array}{c}0.02-0.2 \\
\mathrm{~mm}\end{array}$ \\
\hline $7.95 \pm 2.87$ & $0.54 \pm 0.17$ & $0.61 \pm 0.012$ & $1.28 \pm 0.025$ & $51.7 \pm 0.01$ & $6.14 \pm 0.52$ & $26.17 \pm 3.12$ & $67.13 \pm 3.83$ \\
\hline
\end{tabular}

Rainfall simulator set-up. Four side-sprinkle simulators manufactured by the Institute of Soil and Water Conservation, Chinese Academy of Science and Ministry of Water Resources were used in this experiment. Rainfall height was $5.5 \mathrm{~m}$ and simulated storm with uniformity of above $85 \%$ is similar to natural rainfall in raindrop distribution, raindrop size and terminal velocity. Rainfall intensities can be precisely adjusted through the aperture of nozzle orifice and water pressure. The aperture ranges from $3 \mathrm{~mm}$ to $13 \mathrm{~mm}$ which can produce rainfall intensities of 30-165 mm/h.

Plot characteristics, experimental design and sampling. The experiments were carried out on $8.5 \times 2.5 \mathrm{~m}$ plots with the same slope gradient of $15^{\circ}$. Concrete flumes at the bottom of each plot collected runoff and sediment, and metal troughs at the outlet point of the flume directed runoff into collection containers.

On the Loess Hilly Region, rainfall is concentrated in summer period with high rainfall intensity and short duration typically occurring. Therefore, we designed three representative high rainfall intensity levels in our study: $60 \mathrm{~mm} / \mathrm{h}, 100 \mathrm{~mm} / \mathrm{h}$ and $140 \mathrm{~mm} / \mathrm{h}$, respectively.

Experiments were conducted on dry, windless days to minimize the influence of weather and each rainfall simulation test lasted for $60 \mathrm{~min}$. Before each rainfall simulation test, soil surface samples $(0-5 \mathrm{~cm})$ were collected using a soil auger $(20 \mathrm{~mm}$ in diameter), and then analyzed to determine soil water content, PSD, and different nutrients content. For each test, the time to initiate runoff was recorded. The collection containers at the flume outlets were changed periodically and the time was noted. After the rainfall event was over, the amount of runoff in each collection container was measured. The containers were allowed to stand so that suspended sediment could settle out, then runoff samples were collected from the supernatant using polyethylene bottles and preserved in a refrigerator at $4^{\circ} \mathrm{C}$ until nutrient analysis could be conducted. The supernatant that remained in the collection containers was discarded and the sediment was air-dried, weighed, and sampled. Soil samples were transported in plastic bags to the laboratory for chemical analysis and PSD determination. Rainfall interval was determined according to the initial condition of the plot, especially the antecedent soil moisture. We waited several days until the soil moisture content in each plot returned to the level it was at before the first simulated rainfall event and then repeated the process. All treatments had three replicates.

Measurements. In the laboratory, runoff water samples were filtered through $0.45 \mu \mathrm{m}$ glass fiber filters. The filtered runoff water was analyzed for total dissolved nitrogen (DN) and phosphorus (DP), $\mathrm{NO}_{3}-\mathrm{N}$ and $\mathrm{NH}_{4}-\mathrm{N}$. Sediment samples were analyzed for organic matter (OM), total particulate nitrogen (PN) and phosphorus (PP), $\mathrm{NO}_{3}-\mathrm{N}$ and $\mathrm{NH}_{4}-\mathrm{N}$. DN and PN were measured using the alkaline potassium persulfate oxidation-UV spectrophotometric method and the 
semi-micro Kjeldahl method, respectively. Both $\mathrm{NO}_{3}-\mathrm{N}$ and $\mathrm{NH}_{4}-\mathrm{N}$ were determined with a continuous flow analyzer. Soil organic matter was measured using Potassium dichromate oxidation method. Total $\mathrm{N}$ loss was recorded as the sum of their respective dissolved form in runoff water and the amount of particulate form in sediments. Nutrients background values in the applied rainfall water were subtracted from their contents in the runoff water. The main nutrients parameters calculated for each simulated rainfall event was summarized in Table 2. Texture analysis (International System) was done using laser diffraction method (Malvern Mastersizer 2000 with a Hydro G sample dispersion unit). Similarly, soil samples from each runoff plot collected before each rainfall simulation test were analyzed for the same nutrients following the same procedures described above to determine the enrichment ratio of the sediment. The enrichment ratio (ER) is the concentration of a soil constituent in eroded sediment to that of the original soil from which the sediment originates.

Table 2 Explanatory variables

\begin{tabular}{ll}
\hline Variable & Abbreviation \\
\hline Organic matter & $\mathrm{OM}$ \\
Total phosphorus & $\mathrm{TP}$ \\
Total nitrogen & $\mathrm{TN}$ \\
Ammonium nitrogen & $\mathrm{NH}_{4}-\mathrm{N}$ \\
Nitrate nitrogen & $\mathrm{NO}_{3}-\mathrm{N}$ \\
Mineral/inorganic/organic nitrogen & $\mathrm{MN} / \mathrm{IN} / \mathrm{ON}$ \\
Particulate (Dissolved) phosphorus & $\mathrm{PP}(\mathrm{DP})$ \\
Particulate (Dissolved) nitrogen & $\mathrm{PN}(\mathrm{DN})$ \\
Particulate (Dissolved)organic nitrogen & $\mathrm{PON}(\mathrm{DON})$ \\
Particulate (Dissolved) mineral/inorganic nitrogen & $\mathrm{PMN}(\mathrm{DMN}) / \mathrm{PIN}$ (DIN) \\
\hline
\end{tabular}

Data analysis. An analysis of variance (ANOVA) was used to detect the treatment effects on measured variables. If significant treatment effects were revealed $(p<0.05)$, the Least Significant Difference (LSD) was used to test comparisons among treatment means. Regression analyses were calculated to verify interactions between nutrients loss and soil and water loss, as well as between enrichment ratio of nutrients and enrichment ratio of sediment particle with different diameter. Statistical procedures were carried out with the software package SPSS 13.0 for Windows.

\section{Results}

Hydrological and erosive response. Runoff and sediments collected from different rainfall simulation tests can be an indication of total soil and water losses caused by rainsplash and runoff-driven processes. As can be seen from Table 3, high rainfall intensity events led to high runoff and sediment parameters. Statistically significant differences were found in the hydrological and erosive results. Average runoff ranged from $628.58 \mathrm{~L}$ for $60 \mathrm{~mm} / \mathrm{h}$ to $777.33 \mathrm{~L}$ for $140 \mathrm{~mm} / \mathrm{h}$, increased by $23.66 \%$. Runoff rate ranged from $0.51 \mathrm{~mm} \mathrm{~min}^{-1}$ for $60 \mathrm{~mm} / \mathrm{h}$ to $0.62 \mathrm{~mm} \mathrm{~min}{ }^{-1}$ for $140 \mathrm{~mm} / \mathrm{h}$. No significant differences were detected between $60 \mathrm{~mm} / \mathrm{h}$ and $100 \mathrm{~mm} / \mathrm{h}$ for the hydrological response. Likewise, average sediment yield increased with increasing rainfall intensity. Average erosion rate were $2.50,6.65$ and $8.05 \mathrm{~g} \mathrm{~m}^{-2} \mathrm{~min}^{-1}$ for the three treatments, respectively. Mean sediment concentrations in the $100 \mathrm{~mm} / \mathrm{h}$ and $140 \mathrm{~mm} / \mathrm{h}$ treatments were 12.33 and $12.82 \mathrm{~g} / \mathrm{L}$, respectively, which were 2.5 times of that in $60 \mathrm{~mm} / \mathrm{h}$ treatment. There were no pronounced differences in erosive results between $100 \mathrm{~mm} / \mathrm{h}$ treatment and $140 \mathrm{~mm} / \mathrm{h}$ treatment. Our findings were in agreement with other reports that showed that major runoff and soil loss appear to be result of rainfall intensity $[15,16,17,18]$. 
Table 3 Hydrological and erosive results under different rainfall intensities

\begin{tabular}{cccccc}
\hline $\begin{array}{c}\text { Rainfall intensity } \\
\left(\mathrm{mm} \mathrm{h}^{-1}\right)\end{array}$ & Runoff (L) & $\begin{array}{c}\text { Runoff rate } \\
\left(\mathrm{mm} \mathrm{min}^{-1}\right)\end{array}$ & $\begin{array}{c}\text { Sediment } \\
\left(\mathrm{g} \mathrm{m}^{-2}\right)\end{array}$ & $\begin{array}{c}\text { Erosion rate } \\
\left(\mathrm{g} \mathrm{m}^{-2} \mathrm{~min}^{-1}\right)\end{array}$ & Sediment concentration $\left(\mathrm{g} \mathrm{L}^{-1}\right)$ \\
\hline 60 & $628.58 \mathrm{a}$ & $0.51 \mathrm{a}$ & $145.00 \mathrm{a}$ & $2.50 \mathrm{a}$ & $4.94 \mathrm{a}$ \\
100 & $671.29 \mathrm{a}$ & $0.54 \mathrm{a}$ & $389.03 \mathrm{~b}$ & $6.65 \mathrm{~b}$ & $12.33 \mathrm{~b}$ \\
140 & $777.33 \mathrm{~b}$ & $0.62 \mathrm{~b}$ & $472.00 \mathrm{~b}$ & $8.05 \mathrm{~b}$ & $12.82 \mathrm{~b}$ \\
\hline
\end{tabular}

Means within a column followed by the same letter are not significantly different at 0.05 levels using the least significant difference (LSD) method

Nutrients loss. Along with soil erosion, nutrients were lost also. Taking into account the amount of runoff, sediment and the average nutrients concentration, the total losses of nutrients in each rainfall simulation test were calculated (Table 4). Nutrients losses increased with the increase of rainfall intensity. OM, TP and TN losses under $140 \mathrm{~mm} / \mathrm{h}$ were 4, 2.5 and 3 times of the value under $60 \mathrm{~mm} / \mathrm{h}$ condition, respectively. In terms of different $\mathrm{N}$ forms, total $\mathrm{N}$ was mainly lost though the sediment rather than runoff water. Particulate $\mathrm{N}$, which was 2 to 7 times of dissolved $\mathrm{N}$, takes 68-88\% of the total $\mathrm{N}$ loss. Organic $\mathrm{N}$ was 3 to 8 times of the inorganic $\mathrm{N}$ (mineral $\mathrm{N}$ ) in the total $\mathrm{N}$ loss. Total inorganic $\mathrm{N}$ loss ranged between 41.87 and $54.71 \mathrm{mg} \mathrm{m}^{-2}$. In contrast to total $\mathrm{N}$ loss, inorganic $\mathrm{N}$ loss was mainly through runoff water instead of runoff sediment, and the former was almost 5 to 15 times of the latter; $\mathrm{NO}_{3}-\mathrm{N}$ loss was obviously higher than $\mathrm{NH}_{4}-\mathrm{N}$ loss and occupied $71-75 \%$ of total inorganic $\mathrm{N}$ loss.

The following results can be obtained based on the analysis of Table 4: runoff sediment was the primary pathway for the nutrients loss; particulate $\mathrm{N}$, especially its organic form, was the major form of $\mathrm{N}$ loss; soluble $\mathrm{NO}_{3}-\mathrm{N}$ and $\mathrm{NH}_{4}-\mathrm{N}$ were also the important forms of inorganic $\mathrm{N}$ loss; though organic $\mathrm{N}$ comprised the largest proportion of total $\mathrm{N}$ loss, the mineral $\mathrm{N}$ loss was indispensable.

Table 4 Nutrients loss under different rainfall intensities

\begin{tabular}{|c|c|c|c|c|c|c|c|c|c|c|c|c|c|}
\hline \multirow{2}{*}{$\begin{array}{c}\text { Rainfall } \\
\text { intensit } \\
y \\
(\mathrm{~mm} / \mathrm{h})\end{array}$} & \multirow{2}{*}{$\begin{array}{l}\mathrm{OM} \\
\left(\mathrm{g} / \mathrm{m}^{2}\right. \\
\quad)\end{array}$} & \multirow{2}{*}{$\begin{array}{c}\mathrm{TP}^{\mathrm{a}} \\
\left(\mathrm{mg} / \mathrm{m}^{2}\right. \\
)\end{array}$} & \multirow{2}{*}{$\begin{array}{c}\mathrm{TN} \\
\left(\mathrm{mg} / \mathrm{m}^{2}\right. \\
)\end{array}$} & \multicolumn{5}{|c|}{$\mathrm{N}$ loss in sediments $\left(\mathrm{mg} / \mathrm{m}^{2}\right)$} & \multicolumn{5}{|c|}{$\mathrm{N}$ loss in runoff water $\left(\mathrm{mg} / \mathrm{m}^{2}\right)$} \\
\hline & & & & $\mathrm{PN}$ & $\begin{array}{c}\mathrm{NH}_{4}- \\
\mathrm{N}\end{array}$ & $\begin{array}{c}\mathrm{NO}_{3}- \\
\mathrm{N}\end{array}$ & $\mathrm{MN}$ & ON & $\mathrm{DN}$ & $\begin{array}{c}\mathrm{NH}_{4-} \\
\mathrm{N}\end{array}$ & $\begin{array}{c}\mathrm{NO}_{3}- \\
\mathrm{N}\end{array}$ & $\mathrm{MN}$ & ON \\
\hline 60 & 0.89 & 119.93 & 155.22 & $\begin{array}{c}106.3 \\
6\end{array}$ & 1.42 & 1.12 & $\begin{array}{c}2.5 \\
3\end{array}$ & $\begin{array}{c}103.8 \\
3\end{array}$ & $\begin{array}{c}48.8 \\
6\end{array}$ & 9.17 & 30.17 & $\begin{array}{c}39.3 \\
4\end{array}$ & 9.52 \\
\hline 100 & 2.11 & 233.23 & 243.60 & $\begin{array}{c}191.4 \\
5\end{array}$ & 3.20 & 3.24 & $\begin{array}{c}6.4 \\
4\end{array}$ & $\begin{array}{c}185.0 \\
1\end{array}$ & $\begin{array}{c}52.1 \\
5\end{array}$ & 10.05 & 30.31 & $\begin{array}{c}40.3 \\
6\end{array}$ & 11.79 \\
\hline 140 & 3.54 & 303.69 & 485.24 & $\begin{array}{c}425.4 \\
5\end{array}$ & 4.83 & 3.99 & $\begin{array}{c}8.8 \\
2\end{array}$ & $\begin{array}{c}416.6 \\
2\end{array}$ & $\begin{array}{c}59.7 \\
9\end{array}$ & 10.97 & 34.91 & $\begin{array}{c}45.8 \\
9\end{array}$ & $\begin{array}{c}13.9 \\
1\end{array}$ \\
\hline
\end{tabular}

Components of the nutrients viz. organic matter, total $\mathrm{N}$, total $\mathrm{P}$ and total $\mathrm{K}$ are basic constituents of the soil medium which undergoes erosion due to the action of rainfall and runoff. The amount of nutrient loss therefore, is directly proportional to the amount of soil erosion [19]. Linear regression analysis between nutrients loss and soil erosion indeed indicated significant coefficients of determination (Table 5). This finding is in agreement with Kothyari [19] who reported linear relationships among rainfall, runoff, sediment, and nutrients load under different land uses in Bhetagad watershed of Central Himalaya and is also consistent with Ramos and Martínez-Casasnovas [20] who found higher correlation coefficient between N, P losses and soil losses in vineyards of the Penedés area (north-eastern Spain).

The average ER of different nutrient species was in the order of $E_{N}(1.6)>E R_{O M}(1.2)>E_{P}$ (1.1) (Fig. 2). ANOVA showed that effect of rainfall intensity on $E R_{N}$ was significantly different at 0.01 levels. For $\mathrm{ER}_{\mathrm{OM}}$ and $\mathrm{ER}_{\mathrm{P}}$, the effects were not so pronounced in comparison to $\mathrm{ER}_{\mathrm{N}}$, which can also be seen from Fig. 2 . 
Table 5 Correlation analysis between nutrients loss and runoff, sediment loss

\begin{tabular}{cccc}
\hline Regression function & $R^{2}$ & Regression function & $R^{2}$ \\
\hline OM=0.0067S-0.0704 & 0.7922 & PN=0.7666S-15.986 & 0.7162 \\
PP=0.578S+25.114 & 0.9499 & DN=0.087R-5.8837 & 0.9823 \\
\hline
\end{tabular}

S: sediment; R: runoff

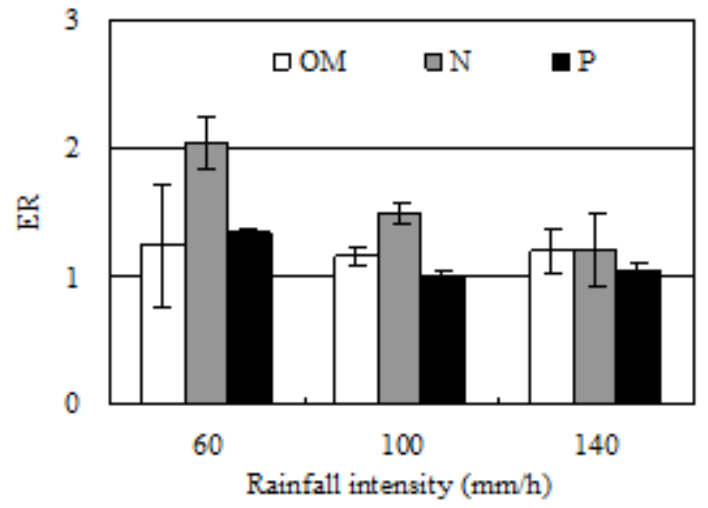

Fig.2 Enrichment ratios (ER) of sediment-associated nutrients

Effect of rainfall intensity on sediment particle size distribution. Compared to the original soil, runoff sediment contained considerably more clay $(<2 \mu \mathrm{m})$ and silt $(2-20 \mu \mathrm{m})$ (Table 6). Less fine sand $(20-200 \mu \mathrm{m})$ was observed in sediments in comparison to original surface soil. The percentage of clay significantly decreased with increasing rainfall intensity $(p<0.05)$. The clay $(<2 \mu \mathrm{m})$ fraction of the sediment in runoff had an enrichment ratio of clay between 1.7 and 2.1 followed by silt $(0.002-0.02 \mathrm{~mm})$ fraction with an ER ranging from 1.4 to 1.6. This implies that these fractions were more represented in the eroded sediments than in the original soil (Fig. 3).

Table 6 Sediment particle size distribution

\begin{tabular}{ccccc}
\hline \multirow{2}{*}{$\begin{array}{c}\text { Rainfall intensity } \\
\mathrm{mm} / \mathrm{h}\end{array}$} & \multicolumn{4}{c}{ Particle size distribution $(\mu \mathrm{m}) / \%$} \\
\cline { 2 - 5 } & $<2$ /Clay & 2-20/Silt & 20-200/Fine sand & 200-2000 /Coarse sand \\
\hline 60 & 11.92 & 38.84 & 46.38 & 2.86 \\
100 & 10.31 & 37.97 & 51.07 & 0.66 \\
140 & 9.38 & 34.40 & 55.65 & 0.56 \\
\hline
\end{tabular}

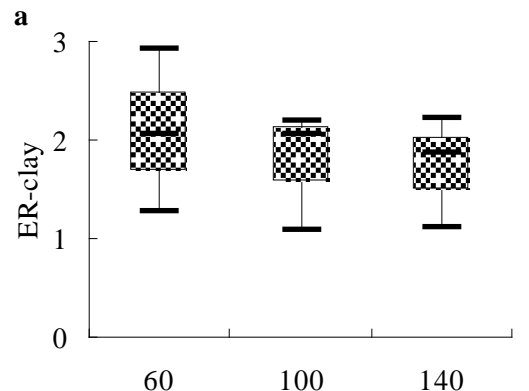

Rainfall intensity $(\mathrm{mm} / \mathrm{h})$

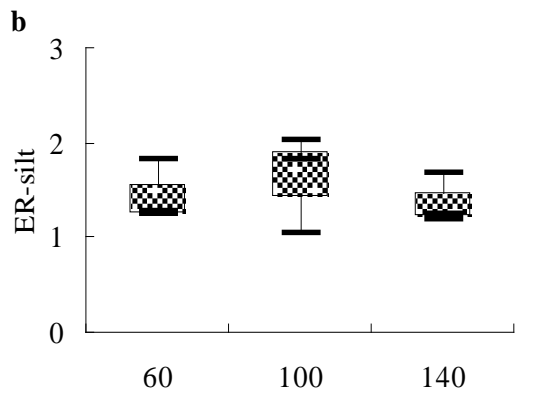

Rainfall intensity (mm/h) 


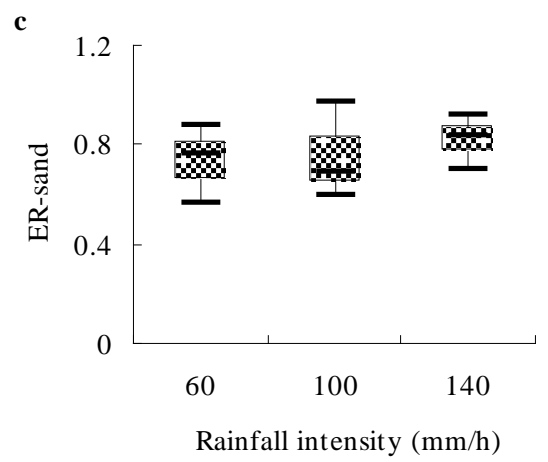

Fig.3 Box-plots for the enrichment ratios (ER) of sediment particles

Fig.4 depicts the relationship between ER of clay and sediment-associated nutrients. Positive linear relationships were identified between ER of the clay $(<2 \mu \mathrm{m})$ and ER of sediment-associated nutrients. There was no clear relationship between ER of silt and ER of the nutrients.
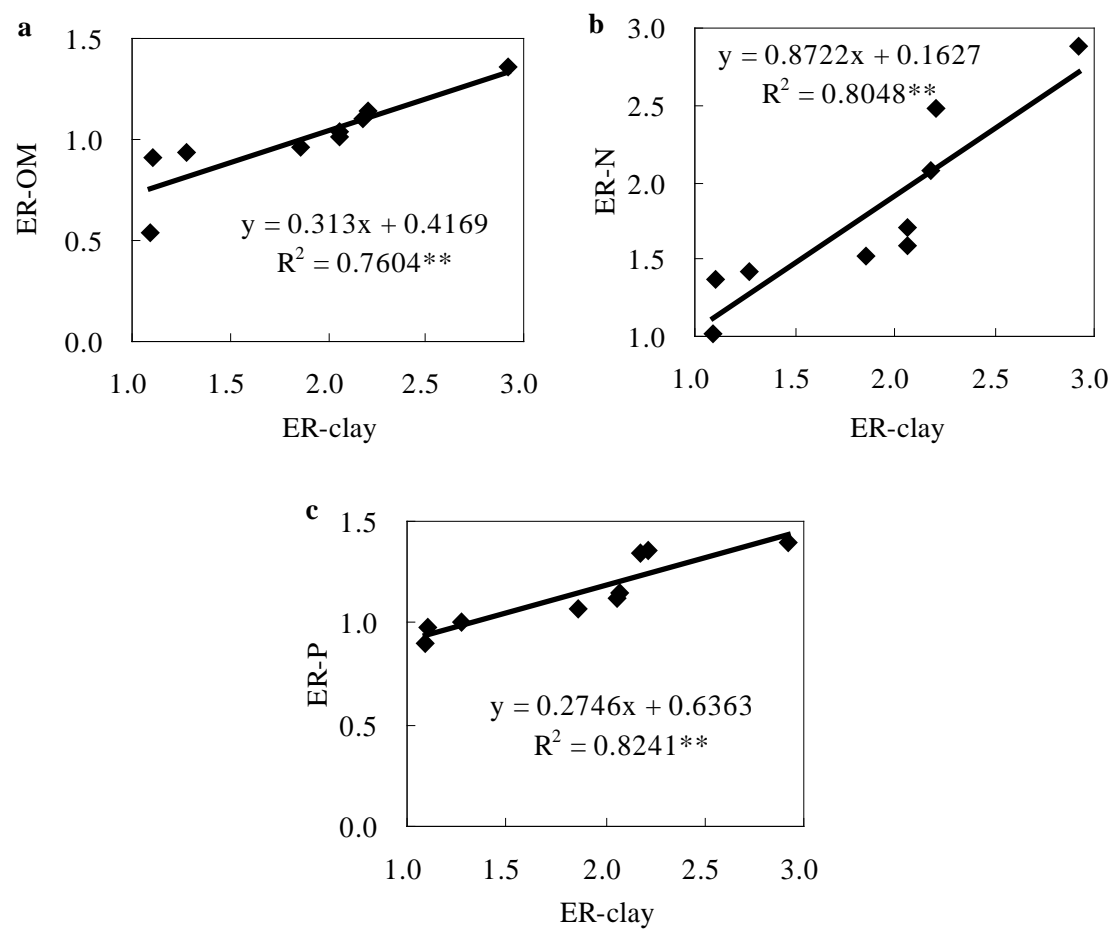

Fig.4 Relationships between ER of clay and sediment-associated nutrients

\section{Discussion}

The present study showed that rainfall intensity had important effect on soil erosion and the related nutrients loss. As concurs with many previous studies [15, 21, 22, 23], high rainfall intensity favors more soil and nutrients loss. In addition, regression analysis demonstrated significantly positive linear relationships between nutrients loss and runoff, sediment loss.

Soil nutrients loss by slope runoff mainly behaved in two ways: runoff sediment and runoff water, and both played different leading role according to the surface condition [24]. In agriculture slope land, the eroded sediment was the primary pathway for soil nutrients loss [25]. Hamilton [26] also reported that in Loess Plateau of China, 98\% of nutrients loss was through sediment. We got the similar result that in our experiment conditions, $\mathrm{P}$ totally lost through sediment and sediment-associated $\mathrm{N}$ accounted for $69-88 \%$ of TN loss. However, Ma et al. [27] found that for the red soil, soil nutrients loss mainly via sediment under higher rainfall intensity; under lower rainfall intensity, the dissolved nutrients in runoff water occupied a higher proportion. The differences may be attributed to the soil type and the selection of rainfall intensity. 
It is well known that fine particles are generally preferentially eroded compared with coarse ones. The significant increase in fine fractions $(<20 \mu \mathrm{m})$ in the sediment in our study means that for this sandy loam soil with nearly $70 \%$ sand, particles smaller than $20 \mu \mathrm{m}$ are susceptible to selective erosion, while higher rainfall intensity and amount of rainfall and subsequent higher runoff might be required to move the larger sand particles. Jin et al. [28] also found similar findings in this respect. However, there were inconsistent view points on the size distribution of the primary particles of the eroded sediment. Rhoton et al. [29] suggested that the clay fraction $(<2 \mu \mathrm{m})$ was preferentially eroded, while Stone and Walling [30] concluded that selective mobilization meant that clay $(<2 \mu \mathrm{m})$ and silt-sized material $(2-63 \mu \mathrm{m})$ were eroded preferentially and that the majority of the sand-sized material was not mobilized. Basic et al. [31] also stated that eroded sediment was generally richer in silt and clay compared with the original soil. Ghadiri and Rose [32] found that the proportion of large aggregates in the eroded sediment was less than in the original soil, and the intermediate size fractions remained unchanged.

The significantly positive correlations between ER of clay fraction and nutrients in the sediment implied that nutrients were mainly adsorbed on or contained within small-sized particles $(<2 \mu \mathrm{m})$. This result has also been examined by other researchers [32, 33, 34], which further confirmed our results of nutrients enrichment in sediments. Jolivet et al. [35] found that the amounts of soil organic matter and soil fertility are positively correlated with the clay and the silt fractions. Moreover, the transport of nutrient-enriched particles may result in the pollution of water bodies such as groundwater, rivers and lakes [10]. From these two respects, the loss of clay and silt in our experiments implies that the soil is experiencing quality deterioration.

\section{Conclusions}

Field simulated rainfall experiments were conducted to explore the influence of rainfall intensity on runoff, sediment yield and nutrients loss, as well as the characteristics of sediment particle size distribution. The results showed that runoff, sediment and nutrients loss increased with the increasing of rainfall intensity. The nutrients mainly lost through runoff sediment. Inorganic $\mathrm{N}$ loss was mainly in runoff water and primarily consisted of $\mathrm{NO}_{3}-\mathrm{N}$. The analysis of the sediment particle size distribution revealed that compared with the original surface soil, the sediment contained more fine particles $(<20 \mu \mathrm{m})$; the dominant particle size fractions that were removed by erosion were comprised in the clay $(<2 \mu \mathrm{m})$. Enrichment ratios for organic matter, $\mathrm{N}$ and $\mathrm{P}$ were positively correlated with enrichment ratio of particles smaller than $2 \mu \mathrm{m}$, and this implies that a large portion of soil nutrients were selectively transported. These results are important for understanding the soil particle distribution and losses resulting from soil erosion and deposition.

\section{Acknowledgment}

This study was supported by the National Natural Science Foundation of China (41301298, 41301201) and the Basic Research Fund for Central Public Research Institutes (CKSF2014025/TB).

\section{References}

[1] M. Mamo, G. D. Bubenzer, Detachment rate, soil erodibility and soil strength as influenced by plant roots. Part 1: Laboratory study,Trans.Am.Soc.Agr.Eng. 44(2001) 1167-1174.

[2] X. He, Z. Li, M.Hao, K. Tang, F. Zheng, Down-scale analysis for water scarcity in response to soil-water conservation on Loess Plateau of China, Agricult. Ecosys. Environ. 94 (2003)355-361.

[3] F. L. Zheng, X. B. He, X.T. Gao, C.E. Zhang, K.L. Tang, Effects of erosion patterns on nutrient loss following deforestation on the Loess Plateau of China, Agricult. Ecosys. Environ. 108(2005)85-97. 
[4] B. Z. Liu, F. Q.Wu, Soil Erosion,Yangling, China, Shaanxi People Press. 233pp, 1996. (in Chinese).

[5] I. García Rodeja, F. Gil-Sotres, Prediction of parameters describing phosphorus-desorption kinetics in soils of Galicia (northwest Spain), J. Environ. Qual. 26(1997)1363-1369.

[6] L.L. Kang, X.Y. Zhu, Y.Z. Wang, Q. Wu, Research on nutrients loss from a loessial soil under different rainfall intensities, Acta Pedologica Sinica. 36(1999)536-543. (in Chinese)

[7] Y.Zhang, Research Advance on Soil Erosion in Loess Hilly-gully Region, Journal of soil and water conservation. 15(2001)121-128. (in Chinese)

[8] F. Gregory, Nitrogen and phosphorus in eroded sediment from corn and soybean tillage system, J Enviorn Qual. 20(1991) 663-670.

[9] G. Catroux, M. Schnitzer, Chemical, spectroscopic, and biological characteristics of the organic matter in particle size fractions separated from an Aquoll, Soil Sci. Soc. Am. J. 51(1987)1200-1207

[10]L. Pieri, M. Bittelli, M. Hanuskova, M. Hanuskova, F. Ventura, A. Vicari, P.R. Pisa, Characteristics of eroded sediments from soil under wheat and maize in the North Italian Apennines, Geoderma. 154 (2009)20-29.

[11]L.D. Meyer, W.C. Harmon, L.L. McDowell, Sediment sizes eroded from crop row side slopes, Transactions of the ASAE 23(1980)891-898.

[12]W.S. Merritt, R.A. Letcherb, A.J. Jakemanb, A review of erosion and sediment transport models, Environ. Model. Softw. 18 (2003)761-799.

[13]M.A. Nearing, V. Jetten, C. Baffaut, O. Cerdan, A. Couturier, M. Hernandez, Y. Le Bissonnais, M.H. Nichols, J.P. Nunes, C.S. Renschler, V. Souchere, K.Van Oost, Modeling response of soil erosion and runoff to changes in precipitation andcover, Catena 61(2005)23.

[14]L. Pieri, M. Bittelli, J. Wu, S. Dun, D. Flanagan, P. Rossi Pisa, F. Ventura, F. Salvatorelli, Using the water erosion prediction project (WEPP) model to simulate field observed runoff and erosion in the Apennines Mountain Range, Italy, J. Hydrol. 336 (2007) 92-97.

[15]J.M. Reichert, L.D. Norton, C. Huang, Sealing, amendment and rain intensity effects on erosion of high clay soils, Soil Sci.Soc.Am.J. 58(1994)1199-1205.

[16]M. Martinez-Mena, V. Castillo, J. Albadalejo, Hydrological and erosional response to natural rainfall in semi-arid area of south-east Spain, Hydrol. Processes. 15(2001)557-571.

[17]J. Arnaez, T. Lasanta, P. Ruiz-Flanňo, L. Ortigosa, Factors ffecting runoff and erosion under simulated rainfall in Mediterranean vineyards, Soil\&Tillage Research. 93(2007)324-334.

[18]G. R. Hancock, A catchment scale assessment of increased rainfall and storm intensity on erosion and sediment transport for Northern Australia, Geoderma. 152(2009):350-360

[19]B.P. Kothyari, V P.K.erma, B.K. Joshi, U.C. Kothyari, Rainfall-runoff-soil and nutrient loss relationships for plot size areas of bhetagad watershed in Central Himalaya, India, Journal of Hydrology. 293(2004)137-150.

[20]M.C. Ramos, J.A. Martínez-Casasnovas, Nutrient losses by runoff in vineyards of the Mediterranean Alt Penedés region (NE Spain), Agriculture, Ecosystems and Environment. 113(2006)356-363.

[21]Zhang, Y.L., Zhang, X.C., Shao, M.A., Li, S.Q., 2004. Impact of rainfall intensity on soil mineral nitrogen loss by runoff on loess slope. Transactions of the CSAE. 20(3): 55-58. (in Chinese) 
[22]W.P. Spann, A.F.S. Sikking, W.B. Hoogmoed, Vegetation barrier and tillage effects on runoff and sediment in an alley crop system on a Luvisol in Burkina Faso, Soil Tillage Res. 83(2005)194-203.

[23]F. Shigaki, A. Sharpley, L. I. Prochnow, Rainfall intensity and phosphorus source effect s on phosphorus transport in surface runoff from soil trays, Science of the Total Environment. 373(2007) 334-343.

[24]A. N. Sharpley, The enrichment of soil phosphorus in runoff sediments, J. Environ Qual. 9(1983) 521 - 526.

[25]Q.H. Meng, L.Z.Yang, Nutrient losses in different land use types in the Three Gorge Reservior Area (TGRA). Acta Ecologica Sinica. 20(2000)1028-1033

[26]E.I. Hamilton, Laboratory manual for the examination of water, waste water and soil, The Science of The Total Environment. 92(1990)289

[27]K. Ma, Z.X. Wang, X. Chen, L. You, Study on Properties of Nutrient Loss from Red Soil in Sloping Land under Different Rainfall Intensities. 16(2002)16-19

[28]K. Jin, W.M. Cornelis, D. Gabriels, M. Baert, H.J. Wu, W. Schiettecatte, D.X. Cai, S. De Neve, J.Y. Jin, R. Hartmann, G. Hofman, Residue cover and rainfall intensity effects on runoff soil organic carbon losses, Catena.78( 2009) 81-86

[29]F.E. Rhoton, N.E. Smeck, L.P. Wilding, Preferential clay mineral erosion from watersheds in the Maumee River Basin, J. Environ. Qual. 8(1979)547-550

[30]P.M. Stone, D.E. Walling, The particle-size selectivity of sediment mobilization fromDevon hillslopes. In: Anderson,M.G., Brooks, S.M. (Eds.), Advances in Hillslope Processes, vol. 1. John Wiley and Sons Ltd., 1996, pp. 507-527.

[31]F. Basic, I. Kisic, O. Nestroy, M. Mesic, A. Butorac, Particle size distribution (texture) of eroded soil material, Journal of Agronomy and Crop Science. 188(2002)311-322.

[32]H. Ghadiri, C.W. Rose, Sorbed chemical transport in overland flow. 1. A nutrient and pesticide enrichment mechanism. J. Environ. Qual. 20(1991)628-633.

[33]J.N. Quinton, J.A. Catt, T.M. Hess, The selective removal of phosphorus from soil: is event size important? J. Environ. Qual. 30(2001) 538-545.

[34]P.A. Jacinthe, R. Lal, L.B. Owens, D.L. Hothem, Transport of labile carbon in runoff as affected by land use and rainfall characteristics, Soil Tillage Res. 77(2004)111-123.

[35]C. Jolivet, D. Arrouays, J. Leveque, F. Andreux, C. Chenu, Organic carbon dynamic in soil particle size separates of sandy Spososols when forest is cleared for maize cropping, Eur. J. Soil Sci. 54(2003)257-268. 